\title{
Caring for family caregivers: An analysis of a family-centered intervention
}

\author{
CUIDAR A LA CUIDADORA FAMILIAR: ANÁLISIS DE UNA INTERVENCIÓN CENTRADA EN LA \\ FAMILIA
}

CUIDANDO DO CUIDADOR FAMILIAR: ANÁLISE DE UMA INTERVENÇÃO CENTRADA NA FAMÍLIA

\author{
Carme Ferré-Grau', Maria Sevilla Casado², Dolors Cid-Buera ${ }^{3}$, Mar LLeixà-Fortuño4, \\ Pilar Monteso-Curto ${ }^{5}$, Marta Berenguer-Poblet ${ }^{6}$
}

\begin{abstract}
Objective: To assess the effectiveness of Problem-Solving Therapy (PST) on family caregivers through the use of scales to measure anxiety, depression and emotional distress; and to explore facilitating factors and obstacles for its use based on the narrative of nurses. Method: A clinical trial and an exploratory focus group with the use of mixed analysis methodology. The study was conducted in a primary health care center in Tarragona, Spain, and the sample consisted of 122 family caregivers who were included in the home care service, and 10 nurses who participated in the intervention group. Family caregivers with evident symptoms of anxiety, depression and emotional distress received PST in the intervention group. The intervention group also consisted of a discussion with eight nurses, which was transcribed and submitted to content analysis. Conclusion: Problem-Solving Therapy proved to be effective in reducing perceived anxiety, depression and emotional distress. We identified its strong points and obstacles as described by nurses.
\end{abstract}

\section{DESCRIPTORS \\ Disabled persons \\ Caregivers \\ Family \\ Stress, psychological \\ Family nursing}

\section{RESUMO}

Objetivo: Avaliar a efetividade da Técnica de Resolução de Problemas (TRP) em cuidadores familiares mediante escalas positivas de ansiedade, depressão e stress emocional; explorar os fatores facilitadores e as barreiras para sua aplicação a partir das narrativas das enfermeiras. Método: Ensaio clínico e grupo focal exploratório, com metodologia de análise mista. Realizado em centros de cuidados primários em Tarragona (Espanha), cuja amosta foi de 122 cuidadores familiares, incluindo atendimento domiciliar e 10 enfermeiros no grupo de intervenção. Grupo implementação experimental do TRP, cuidador familiar com sintomas de ansiedade, depressão e desconforto percebido. No grupo controle a enfermeira executa a intervenção habitual. Feita medição pré e pós intervenção em ambos os grupos. Grupo de discussão com oito enfermeiros do grupo de intervenção, transcrição e análise de conteúdo. Conclusão: Ficou demonstrada a eficácia da TRP na redução da ansiedade, depressão e desconforto percebido. Foram identificados os pontos fortes e as barreiras na aplicação da técnica.

\author{
DESCRITORES \\ Pessoas com deficiência \\ Cuidadores \\ Família \\ Estresse psicológico \\ Enfermagem familiar
}

\section{RESUMEN}

Objetivo: Evaluar la efectividad de la Técnica de Resolución de Problemas (TRP) en cuidadoras familiares mediante escalas positivas de ansiedad, depresión y malestar emocional; explorar los factores facilitadores y barreras en su aplicación a partir de la narrativa de las enfermeras. Método: Ensayo clínico y grupo focal exploratorio y metodología de análisis mixta. Ilevado a cabo en el Centro de Atención Primaria de Tarragona (España), cuya muestra fue 122 cuidadoras familiares incluidas en el programa de atención domiciliaria y 10 enfermeras del grupo intervención. Grupo experimental aplicación de la TRP, a la cuidadora familiar con síntomas de ansiedad, depresión y malestar percibido. Grupo control la enfermera realiza la intervención habitual. Medición pre-post en ambos grupos. Grupo de discusión con ocho enfermeras del grupo intervención, trascripción y análisis del contenido. Conclusión: Se demuestra la efectividad de la TRP en la reducción de ansiedad, depresión y malestar percibido. Se identifican los puntos fuertes y las barreras descritas por las enfermeras en la aplicación de la técnica.

DESCRIPTORES
Personas com discapacidad
Cuidadores
Familia
Estrés psicológico
Enfermería familiar

\footnotetext{
${ }_{1}^{1}$ Professor and responsible for the Doctoral Program in Nursing Science, College of Nursing, University of Rovira i Virgili, Tarragona, Spain. ${ }^{2}$ Postdoctoral student, Catholic University of Leuven, Belgium ${ }^{3}$ Professor of Community Nursing and Public Health, Department of Nursing, University of Rovira i Virgili, Tarragona, Spain. ${ }^{4}$ Professor and responsible for the Master's in Nursing Science Program, College of Nursing, University of Rovira i Virgili, Tarragona, Spain. ${ }^{5}$ Professor and responsible for the Master's in Aging and Health Program, University of Rovira i Virgili, Tarragona, Spain. ${ }^{6}$ Doctoral student,
} Nursing Science Program, University of Rovira i Virgili, Tarragona, Spain. 


\section{INTRODUCTION}

The increase in life expectancy and lowered birth rates have led to population aging and a greater prevalence of chronic diseases. According to a study conducted in 2002 by the European Commission, the number of people aged 65 years and over in the European Union will increase from 61 million, as recorded in 2000, to a projected 103 million in 2050.(1) The Libro Blanco de la Dependencia, a white paper on the care of dependent persons, published in Spain in 2004 indicated that $16.6 \%$ of Spanish adults are 65 years and older and this figure is expected to grow in the coming years. ${ }^{(2)}$ In Spain, an estimated $1,067,818$ people are in need of care due to longevity and dependency.

The first exhaustive study conducted in Spain by the Institute for Older Persons and Social Services ${ }^{(3)}$ (IMSERSO) about family caregivers of persons with dependency demonstrated the discomfort they experienced, especially regarding loss of free time, decreased social activities, deterioration of their own health, work problems and changes in family life. Caring becomes a daily routine that occupies a great part of caregivers' resources and energy. The provision of care within a family does not occur evenly among its members. Instead, one family member takes on the greatest responsibility, becoming the primary caregiver. The typical profile of those who provide care in Spain can be summarized in the following phrase: female and sole caregiver. For the most part, women are the ones who take on the role of family caregivers for the chronically ill. They must perform numerous tasks and make complex decisions on a daily basis. This places them in situations of high vulnerability, stress, and uncertainty. Thus, providing them with interventions that support their caregiving work is necessary. ${ }^{(4-9)}$

In the Spanish social context, family caregivers are the reference point for persons with dependency; their affection and attention are indispensable in order to ensure the patient's quality of life. However, providing affection requires time and effort. Affection between caregivers and those who receive care takes place in a context of complex interactions in which both positive and negative emotions circulate. Most caregivers have the feeling of being physically and emotionally trapped. Nurses working in home care must play the role of collaborator, negotiator and coordinator, helping caregivers learn effective adaptation strategies when faced with difficult decisions. Enhancing and maintaining primary caregivers' health contributes toward improving overall family health. ${ }^{(10-11)}$

In literature review studies on the effectiveness of interventions aimed at reducing the discomfort of those who care for the chronically ill, despite the diversity of methods and techniques used, (12-13) authors concluded that cognitive-behavioral techniques, together with psychological support for caregivers, could be more effective than educational programs and support groups alone. ${ }^{(14)}$
Problem-Solving Therapy (PST) is a non-specialized, relatively brief and easy-to-learn technique. Therefore, it can be feasibly developed on any health care level when attending to patients and their families. ${ }^{(15)}$ Studies on PST used by nursing staff in other countries have obtained very satisfactory results with this technique. (16) Problem-Solving Therapy has proven to be a useful tool in any stressful situations in which human beings find themselves, although the most common are physical or psychological illness, where there is real or feared loss of interpersonal relationships or personal conditions and when important decisions must be made. ${ }^{(17)}$ Many of these situations are inherent to the caregiving process in the family setting when a condition of chronicity and dependency is prolonged.

The present article aimed to assess the effectiveness of PST with family caregivers who presented positive scores on anxiety and/or depression scales and altered scores relating to emotional distress. It also aimed to explore factors that could hinder its systematic use.

\section{METHOD}

This was a clinical trial consisting of an Intervention Group (IG) and a Control Group (CG) with pre - and postintervention data collection.

\section{Population and sample}

The study sample consisted of 122 family caregivers who met the following inclusion criteria: Providing care to chronically ill persons registered with the home care service for chronic patients (ATDOM) for at least four months; and displaying a positive score on the Goldberg anxiety and/or depression scales and alterations on the emotional well-being scale (Nursing Outcomes Classification - NOC) at the time of the intervention. ${ }^{(18-19)}$ We excluded family caregivers with sensory and/or cognitive disabilities that could hinder comprehension of PST and caregivers who did not consent to the intervention, despite having presented positive results on the questionnaires. We also excluded caregivers whose family members died during the intervention period.

The effectiveness of PST was evaluated based on the results of the Goldberg anxiety and depression questionnaires and the emotional wellbeing scale a month after the intervention (post-test), comparing them to the results obtained at the start (pre-test).

Ten home care nurses, who were trained to carry out PST, conducted the intervention. The nurses were assigned to chronic patients attended to by the primary health care center in which they worked. Therefore, the nurses were already familiar with both patients and caregivers. (One of the inclusion criteria for the ATDOM program is that a reference family caregiver be registered.)
Caring for family caregivers: An analysis of a familycentered intervention Ferré-Grau C, Casado MS, Cid-Buera D, LLeixà-Fortuño M, Monteso-Curto $P$, Berenguer-Poblet $M$ 
The intervention protocol was agreed upon by the nurses and we allowed the intervention to be adapted according to their time and availability. A maximum of five sessions were arranged, and in each, nurses and family caregivers worked on the different steps of PST. These sessions took place during the nurses' regular weekly home visit.

Before conducting PST, nurses participated in a training seminar. Throughout the process, researchers were available to address any questions that arose during the intervention, both online and on the telephone. Nurses were given didactic and bibliographic material specifically designed for the present research. ${ }^{(20)}$

In each session, nurses recorded data regarding their experience with conducting PST during the intervention period (Annex 1).

After obtaining the statistical results of the trial's quantitative assessment phase, intervention group nurses were contacted once more to participate in an exploratory focus group. This group aimed to identify which factors facilitated the nurses' use of PST and which made it difficult to put knowledge obtained by this study into practice. The focus group was conducted by two researchers who had not been directly involved in advising and assisting the nurses during the intervention process. This was done so that familiarity with the researchers would not contaminate the focus groups' discourse.

All phases of the study abided by the ethical principles set forth in the Helsinki declaration for clinical research. The study was approved by the ethics committee for clinical research in primary health care (IDEAP) of the Jordi Gol University Institute in October 2007 (P07/40) and took place in Spain between 2007 and 2012. All caregivers and nurses were informed of their confidentiality and signed a Free and Informed Consent form.

\section{Quantitative analysis}

Data analysis was conducted with SPSS $17.0^{\circ}$ statistical software for Windows. Descriptive analysis was used for all the variables according to their nature. Qualitative data were analyzed using frequencies and percentages for each category and then placed in charts and figures. Quantitative measurements were analyzed according to central tendency, mean, median and standard deviation values, as well as range or amplitude. In order to compare pre - and post-intervention differences, we used Student's t-test. For all tests we adopted a 95\% ( $p<0.05)$ confidence level.

\section{Qualitative analysis}

The focus group session took place in December 2012 and was recorded digitally (Olympus VN-3500PC). Data were analyzed using content analysis based on phenomenology, according to van Manen's(21) recommendations. We explored both the expressed (consciously elaborated) and implicit factors that emerged in discussion regarding the nurses' experiences. In this regard, two aspects were taken into consideration; one related to the nurse-caregiver relationship and the other emphasized the importance of factors that can facilitate or hinder giving continuity to PST in home care intervention.

Three researchers who had not participated in the focus group examined the transcripts to identify factors that can facilitate or hinder the use of PST.

\section{RESULTS}

\section{Quantitative results}

The mean age of the 122 caregivers in this study was 58 years, they were married and had completed only primary school education. Most were daughters of chronic patients and lived with them in $88.3 \%$ of cases. They had been caregivers for over 5 years and the mean time of daily dedication was 21.8 hours. Caregivers had social resources for the caring process $70 \%$ of the time, even though only $45.9 \%$ of participants evaluated such resources positively.

Table 1 displays the mean values for anxiety, depression and emotional well-being obtained pre - and post-intervention for our sample of caregivers. We observed that the values for each of these parameters were reduced in post-intervention data collection. Reductions in anxiety $(p<0.00)$, depression $(p<0.01)$ and perceived emotional well-being $(p<0.03)$ were statistically significant.

Table 1 - Mean values for caregiver anxiety, depression and emotional well-being obtained pre - and post-intervention for the studied group

\begin{tabular}{|c|c|c|c|c|c|c|}
\hline \multirow{2}{*}{ Variables } & \multicolumn{2}{|c|}{ Control Group } & \multicolumn{2}{|c|}{ Intervention Group } & \multirow{2}{*}{$\begin{array}{c}\text { Mean } \\
\text { Difference }\end{array}$} & \multirow[b]{2}{*}{ p } \\
\hline & Mean & SD & Media & DT & & \\
\hline Anxiety & 4.70 & 3.03 & 3.39 & 2.87 & 1.31 & 0.016 \\
\hline Depression & 3.48 & 2.66 & 2.21 & 2.40 & 1.27 & 0.007 \\
\hline $\begin{array}{l}\text { Emotional } \\
\text { well-being }\end{array}$ & 2.72 & 1.08 & 2.32 & 1.08 & 0.40 & 0.051 \\
\hline
\end{tabular}

\section{Qualitative results}

Eight of the ten nurses who had conducted the PST intervention participated in the focus group (two were absent for logistical reasons). The group session lasted 90 minutes and the data were transcribed. The language spoken during the focus group was Catalan. However, for transcription and analysis purposes, the material was translated into Spanish, respecting narrative expressions as much as possible.

The eight nurses of our sample worked in different primary health care centers in the province of Tarragona, where the interventions took place, and all were part of the home care service for chronic patients (ATDOM). The nurses had at least five years of experience working in the program; for identification purposes, we took into account whether the intervention occurred in a rural or urban context. 
The guiding question for the discussion was: What was your experience using PST with family caregivers? Could you see it becoming part of home care service for caregivers of chronically ill persons?

Two thematic categories emerged from the analyzed material: Contributions of PST to caring for caregivers and the difficulties encountered.

\section{Contributions of PST to caring for caregivers}

The nurses all agreed that PST helped personalize the care provided to caregivers and helped in sharing the responsibility for making decisions:

When it's been a while since you've been to a home, you know what to expect... In the end it's all very repetitive...in truth the technique forces you to listen to the caregiver to define and convert the problem into a problem that can be solved... it makes it easier for you to move forward instead of always listening to the same tune (I1 urban).

You ask them, What do you think you could do to feel better? and then pass the decision on to them....in a way you are telling them to get going (I6 urban).

The technique forces us to ask them how they are, how they are experiencing things, and what they have considered doing, it helps clarify if they need any help...thus we can provide more personalized help. (17 rural).

We are there as facilitators, and they are the ones with the responsibility...my experience tells me that when you want to act like a savior, you try very hard to find solutions for them and in the end they don't accept them...They have the power to decide....all you can do is ask, What do you think you can do?...You can set them in motion (I3 urban).

In the beginning I was afraid that I wouldn't know how to use the technique... but I learned that nurses...must stay positive...; ... if you see things are not going well, you must talk with them, let them cry it out and when they have finished, you can suggest a change...; ...you need to ask them what they have already considered doing... (15 rural).

An important element that emerged when analyzing the nurses' discourse was caregivers' gratitude for their work and the recognition of their effort in applying PST. Gratitude from caregivers was one of the aspects that pleasantly surprised the nurses, during and after the intervention:

I remember this one caregiver who had many family problems, she would always come to the primary health care center and complain about everything....after conducting PST, even though not everything was solved, not at all, whenever she came to pick up prescriptions, instead of complaining she would tell me she had made an effort to go to the hair salon, to get out of the house more...I noticed she was more active, motivated and content...her relationship with me improved, I began to see her in different way (E6 urban).
I was very surprised when after conducting PST, the caregiver told me, I feel like it's the first time someone has taken care of me....I don't know...I had been going to her home for more than two years (...) It's a matter of them perceiving that you take an interest in them (E3 urban).

Since the intervention, there is a group of caregivers who go out every day for a walk... when I meet them I feel very happy, for I feel I have helped them to maintain a life of their own beyond caregiving...it seems easy, but it's very difficult (E4 rural).

In the first session, they had a hard time understanding us, but after the 3rd session we noticed many changes, they smiled, they had a different view on things...even though there were some cases in which it was very hard to find solutions (E8 urban).

We observed signs of the nurses' satisfaction with their work through their verbal and non-verbal communication during the focus group. There was a consensus in this regard, for all the nurses reported anecdotes from their practice reflecting this theme.

Another theme that emerged from the intervention and that appeared in all of the nurses' discourses was how PST had facilitated contact and communication among them and with different professionals in the health care team. These accounts described how the caregivers' interpersonal and/or family contacts were improved, which allowed nurses to provide faster, more effective and holistic care.

When you know you have a limited time to help, you are more concerned with providing them with the resources they need...In this one case I spoke to $X$ so that they could provide me with an ambulance so that the husband, who was terminally ill, could travel to Salou...this was very significant to the caregiver (I1 urban).

When you let the caregiver talk, you understand what information she needs, her personal resources... and above all, you are able to notice what helps her and what doesn't (I6 urban).

At home, doctors do not interfere...they leave you be... at home we are the ones with the power...we're the ones who notice if they need anything and can say, You could go and see Mrs. $X$,- in the hospital it is different (E7 rural).

In this one case in which the caregiver and her mother (an Alzheimer's patient) had an extremely bad relationship, I showed her how to give her mother massages, relaxation techniques, and this helped calm the patient and caregiver (I2 urban).

The nurses also mentioned that the intervention seemed to help caregivers ask for help from other family members.

I had this one case in which the caregiver took care of everything when she couldn't do so, because she was also ill...I suggested she talk with the others, I told her to ask 
for help with the things she couldn't do, we talked about who could help her, how things could be arranged, who she could ask for help, right? About who could help her with cooking...groceries...cleaning (I3 urban).

In this other case we talked about how she could keep on seeing her grandchildren without always having to take care of them...she wasn't able to take care of them but she was afraid she wouldn't get to see them otherwise (E5 rural).

To see how they can help each other...that they support each other...especially in families who get along. If they don't, you help them find support outside the family (I2 urban).

During the intervention, we always kept the entire family in mind, even though we only talked with the caregiver... family communication becomes easier (14 rural).

The nurses gave several examples of how PST made it easier to share their achievements and/or the difficulties that appeared throughout the process with other team members. This helped them become more open to learning, especially with respect to how to plan new strategies together with caregivers in order to manage the crises they were experiencing with their caregiving role within the family.

\section{Difficulties detected: The time factor}

One of the difficulties detected and that emerged in the narrative discourses of all the nurses when they discussed using PST in the future was the fear of not having enough time to carry out the technique.

When asked about systematic use of PST, nurses constantly made statements such as:

It's a luxury to spend so much time talking to the caregiver (18 urban).

Some patients are in very good conditions, so nurses have time to sit with the caregiver...however, with others it's hard to be with both at the same time, like we did (I7 rural).

When talking about the hypothetical use of this technique by their coworkers in order to care for caregivers, they mentioned the time factor as an obstacle. Time limitations were related to the general structure of home care and the growing demands of primary health care.

Regarding the time specifically dedicated to PST, we observed ambivalent and contradictory discourses in the group. On the one hand, they stated that they were able to conduct the intervention (as shown in the records) within the designated time. On the other hand, when referring to the future, participants said nurses would not have enough time or skills to provide technical care to chronically ill persons and also talk to caregivers (who are always present in these cases), as they did during the present study.

\section{DISCUSSION}

The results of the clinical trial demonstrated the effectiveness of PST in reducing symptoms of anxiety, depression or emotional distress perceived in family caregivers of chronically ill patients. These results corroborate those of studies conducted in other contexts with different populations, but which presented problems similar to those in this study. ${ }^{(15.22)}$

This study found that PST is cost-efficient, as the intervention with caregivers was carried out by nurses during the time allotted for home care of chronically ill patients. Their records showed that it was possible to conduct the intervention during the time of their home care visits; additional time was needed only in the first session (defining the problem). ${ }^{(23)}$

When analyzing the group discussion, we identified the attitudes and perceptions held by nurses. Some of them act as obstacles and others as facilitating factors in the process of transferring the theoretical knowledge of the present study into practice. These factors must be taken into account when considering the systematic use of PST as a care option for caregivers of chronically ill patients.

Satisfaction and/or recognition, both from caregivers and professionals, stood out as facilitating factors. We also observed that participants considered it a natural part of their role as home care nurses to help family caregivers solve problems, which are not only of the physical dimension, but also psychosocial. In this regard, PST presents itself as a practical, simple method, close to their current practice. We must make the most of this natural selfperception of nurses in order to introduce changes in the approach of caregivers, facilitating their caregiving role in the family setting. Providing such attention to caregivers will foster personal and family health for persons with chronic illnesses cared for at home.

The main resistance factor found was the fear of not having enough time for developing the technique in the future. This issue also appeared as a significant obstacle in another study that investigated PST in the context of medical care, which produced positive results regarding its effectiveness in reducing depression. ${ }^{(24)}$ Considering our context, there are no studies to which this aspect of PST use can be compared, but our findings are in accordance with those of other studies that also detected the problem of the time dedicated to care, which encompasses psychosocial and relational aspects, such as communication, listening, anxiety reduction, emotional support, etc. ${ }^{(25-27)}$

Finally, the qualitative results of our study were centered on the nurses' experiences and their accounts or observations of caregivers. We believe that it would be interesting to conduct further research that includes a discussion group with caregivers who received the intervention. Thus, we would advance in the process of knowledge transfer, taking into account the opinion of all the actors involved in the process. 


\section{CONCLUSION}

The present study demonstrated the effectiveness of PST for reducing symptoms of anxiety, depression and emotional distress of family caregivers of chronically ill and/or dependent persons.

The intervention was cost-effective, as the nurses applied it systematically during their regular ATDOM service home visits.

\section{REFERENCES}

1. Fundación General CSIC. Informe I+D+i sobre envejecimiento. Madrid; 2010.

2. España. Ministerio de Trabajo y Asuntos Sociales; Secretaría de Estado de Servicios Sociales. Familia y Discapacidad. Atención a las personas en situación de dependencia en España: Libro Blanco. Madrid: Observatorio de Personas Mayores del IMSERSO; 2004.

3. España. Ministerio de Educación. Política Social y Deporte; Secretaría de Estado de Política Social. Familia y Discapacidad; Instituto de Mayores y Servicios Sociales (IMSERSO). Las personas mayores en España: informe 2008: datos estadísticos estatales y por Comunidades Autónomas. Madrid: Observatorio de Personas Mayores del IMSERSO; 2009. Tomo 1.

4. Cuellar Flores I. Adaptación psicológica en personas cuidadoras de familiares dependientes. Clín Salud. 2012;23(2):141-52.

5. Anaut-Bravo S. Méndez-Cano J. El entorno familiar ante la provisión de cuidados a personas afectadas de Parkinson. Portularia. 2011;11(1):37-47.

6. Fernández de Larrinoa Palacios P. Martínez Rodríguez S. Ortiz Marqués N. Carrasco Zabaleta M. Solabarrieta Eizaguirre J. Gómez Marroquín I. Autopercepción del estado de salud en familiares cuidadores y su relación con el nivel de sobrecarga. Psicothema. 2011;23(3):388-93.

7. González Pisano AC. Calidad de vida relacionada con la salud en cuidadoras de personas dependientes de dos zonas rurales de León. Enferm Clín. 2009;19(5):249-57.

8. Gratao ACM. Vale FAC. Roriz-Cruz M. Haas VJ. Lange C. Talmelli LFS. Rodrigues RAP. The demands of family caregivers of elderly individuals with dementia. Rev Esc Enferm USP. 2010;44(4):873-80.

9. Zabalegui A. Juando C. Izquierdo MD. Gual P. GonzálezValentín A. Gallart A. et al. Recursos y consecuencias de cuidar a las personas mayores de 65 años: una revisión sistemática. Gerokomos. 2004;15(4):199-208.
Important facilitating factors identified by nurses for using PST consisted of: 1) the personalization of family care, 2) caregivers' recognition and/or gratitude for the nurses' work, 3) teamwork, since PST obliged them to make mediation with other professionals more dynamic or to facilitate the search for health and social resources; and 4) helping caregivers to ask other family members for support. The main obstacle observed was the time factor, since the fear of not having enough time can make it difficult to use the technique systematically every day.

10. Perlini NMOG. Faro ACM. Taking care of persons handicapped by cerebral vascular accident. Rev Esc Enferm USP 2005;39(2):154-63.

11. Ângelo M. Bousso RS. Rossato LM. Damião EBC. Silveira AO. Castilho AMCM. et al. Family as an analysis category and research field in nursing. Rev Esc Enferm USP. 2009;43(n. spe2):1337-41.

12. López J. Crespo M. y Zarit S. Assessment of the efficacy a stress management program for informal caregivers of dependent older adults. Gerontologist. 2007; 47(2):205-14.

13. Torres Egea MP. Ballesteros Pérez E. Sánchez Castillo PD. Programas e intervenciones de apoyo a los cuidadores informales en España. Gerokomos. 2008; 19(1):9-15.

14. Kootker JA. Fasotti L. Rasquin SM. van Heugten CM. Geurts ACh. The effectiveness of an augmented cognitive behavioural intervention for post-stroke depression with or without anxiety (PSDA): the Restore-Stroke-PSDA trial. BMC Neurol; 2012;12:15.

15. García-Campayo J. Claraco-Vega LM. Tazón P. Aseguinolaza L. Terapia de resolución de problemas: psicoterapia de elección para atención primaria. Aten Primaria. 1999;24(10):594-601.

16. Mynors-Wallis L. Davies I. Gray A. Barbour F. Gath D. A randomised controlled trial and cost analysis of problemsolving treatment for emotional disorders given by community nurses in primary care. $\mathrm{Br} J$ Psychiatry. 1997;170:113-9.

17. Bosmans JE. Schreuders B. van Marwijk HW. Smit JH. van Oppen P. van Tulder MW. Cost-effectiveness of problemsolving treatment in comparison with usual care for primary care patients with mental health problems: a randomized trial. BMC Fam Pract. 2012;13:98.

18. Montón Franco C. Pérez Echevarría MJ. Campos R. García Campayo J. Lobo A. Escalas de ansiedad y depresión de Goldberg: una guía de entrevista eficaz para la detección del malestar psíquico. Aten Primaria. 1993;12(1):6-15. 
19. Badia X. Salamero M y Alonso J. La medida de la salud: guía de escalas de medida en español. 4a ed. Barcelona: Edimac; 2007.

20. Ferre-Grau C. Rodero-Sánchez V. Vives-Relats C. Cid-Buera MD. El mundo del cuidador familiar: una visión teórica y un modelo práctico. Tarragona: Silva; 2008.

21. Van Manen M. Investigación educativa y experiencia vivida. Barcelona: Idea Books; 2003.

22. Vázquez González FL. Otero Otero P. Torres Iglesias A. Hermida García E. Blanco Seoane V. A brief problemsolving indicated-prevention intervention for prevention of depression in nonprofessional caregivers. Psicothema. 2013;25(1):87-92.

23. Ferré-Grau-C. Sevilla-Casado M. Lleixà-Fortuño-M. Aparicio-Casals RM. Cid-Buera D. Rodero-Sánchez-V. et al. Effectiveness of problem-solving technique in caring for family caregivers: a clinical trial study in an urban area of Catalonia (Spain). J Clin Nurs. 2014;23(1-2):288-95.
24. Pierce D. Gunn J. GPs' use of problem solving therapy for depression: a qualitative study of barriers to and enablers of evidence based care. BMC Fam Pract 2007;8:24.

25. García Marco MI. López lbort MN. Vicente Edo MJ. Reflexiones en torno a la relación terapéutica: ¿Falta de tiempo? Index Enferm. 2004;13(47):44-8.

26. Daza de Caballero R. Torres Pique AM. Prieto de Romano GI. Análisis crítico del cuidado de enfermería: interacción. participación y afecto. Index Enferm. 2005;14(48-49):18-22.

27. Furegato ARF. Scatena MCM. Formación humanista para el cuidado de enfermería. SMAD Rev Eletr Saúde Mental Álcool Drog [Internet]. 2005 [cited Mar 20 2012];1(1): Available at: http://www.revistas.usp.br/smad/article/ view/38614/41461

\section{Financial support}

The study corresponds to a project that is part of the Spanish National Research Plan, Carlos III Health Institute, through a Fund for Health Research (FIS) grant: exp. PI 070489, co-financed by the European Regional Development Fund (ERDF) 
ANNEX 1

PST Intervention Record Form

Registration number

Nurse's code number

Caregiver's code number

1.- Assessing appropriateness of PST

Intervention implemented Time invested Goal was met

Yes $\square \quad$ No $\square$

Record of observations and/or occurrence

2.- Explaining treatment and its rational basis Intervention implemented Time invested

Yes $\square \quad$ No $\square$

Record of observations and/or occurrence

3.- Recognizing and identifying problems Intervention implemented Time invested

Yes $\square \quad$ No $\square$

Record of observations and/or occurrence

4.- Selecting attainable goals

Intervention implemented

Time invested

Goal was met

Yes $\square \quad$ No $\square$

Yes $\square \quad$ No $\square$

Record of observations and/or occurrence

5.- Generating solutions

Intervention implemented Time invested

Yes $\square \quad$ No $\square$

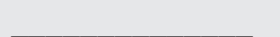

Goal was met

Yes $\square$

No $\square$

Record of observations and/or occurrence

6.- Choosing preferred solution

Intervention implemented Time invested

Goal was met

Yes $\square \quad$ No $\square$

Yes

No $\square$

Record of observations and/or occurrence

7.- The chosen solution was implemented Intervention implemented Time invested

Goal was met

Yes $\square \quad$ No $\square$

Yes $\square$

No $\square$

Record of observations and/or occurrence

8.- Progress Review

Intervention implemented Time invested

Yes $\square \quad$ No $\square$

Goal was met

Record of observations and/or occurrence 